\title{
Friction and Wear Behaviors of Fe-19Cr-15Mn-0.66N Steel at High Temperature
}

\author{
Shaolong Sheng ${ }^{1}$, Huiling Zhou ${ }^{1}$, Xiaojing Wang ${ }^{1} \mathbb{1}$, Yanxin Qiao ${ }^{1,2, *} \mathbb{C}$, Hongtao Yuan ${ }^{3}$, Jian Chen ${ }^{1,4}$, \\ Lanlan Yang ${ }^{1}$, Dongpeng Wang ${ }^{1}$, Zhenguang Liu ${ }^{1}$, Jiasheng Zou ${ }^{1}$, Zhibin Zheng ${ }^{2, *}$ and Jingyong Li $^{1, *}$ \\ 1 School of Materials Science and Engineering, Jiangsu University of Science and Technology, \\ Zhenjiang 212003, China; 152210602420@stu.just.edu.cn (S.S.); zhouhl@just.edu.cn (H.Z.); \\ wxj@just.edu.cn (X.W.); jchen496@uwo.cn (J.C.); lanlanyang@just.edu.cn (L.Y.); dpwang@just.edu.cn (D.W.); \\ zgliu@just.edu.cn (Z.L.); zjzoujs@126.com (J.Z.) \\ 2 Institute of New Materials, Guangdong Academy of Sciences, Guangzhou 510650, China \\ 3 Shanghai Waigaoqiao Shipbuilding Co., Ltd., Shanghai 200137, China; yuanht@chinasws.com \\ 4 Department of Chemistry, Western University, 1151 Richmond St., London, ON N6A 5B7, Canada \\ * Correspondence: yxqiao@just.edu.cn (Y.Q.); zbzheng712003@163.com (Z.Z.); jingyong_li@126.com (J.L.)
}

check for

updates

Citation: Sheng, S.; Zhou, H.; Wang, X.; Qiao, Y.; Yuan, H.; Chen, J.; Yang,

L.; Wang, D.; Liu, Z.; Zou, J.; et al.

Friction and Wear Behaviors of Fe-19Cr-15Mn-0.66N Steel at High Temperature. Coatings 2021, 11, 1285. https://doi.org/10.3390/

coatings11111285

Academic Editor: Alina Vladescu

Received: 28 August 2021

Accepted: 19 October 2021

Published: 22 October 2021

Publisher's Note: MDPI stays neutral with regard to jurisdictional claims in published maps and institutional affiliations.

Copyright: (C) 2021 by the authors. Licensee MDPI, Basel, Switzerland. This article is an open access article distributed under the terms and conditions of the Creative Commons Attribution (CC BY) license (https:/ / creativecommons.org/licenses/by/ $4.0 /)$.

\begin{abstract}
The friction and wear behaviors of Fe-19Cr-15Mn-0.66N steel were investigated under applied loads of $5 \mathrm{~N}$ and $15 \mathrm{~N}$ at the wear-testing temperatures of $300{ }^{\circ} \mathrm{C}$ and $500{ }^{\circ} \mathrm{C}$ using a ball-on-disc tribometer. The wear tracks were evaluated by scanning electron microscopy (SEM) and laser scanning confocal microscopy (LSCM) to reveal the variation in morphologies. Energydispersive X-ray spectroscopy (EDS) and X-ray photoelectron spectroscopy (XPS) were used to determine the components of oxide layers formed on wear surfaces. The results demonstrated that the oxide layers are favorable for obtaining a low friction coefficient under all conditions. The average friction coefficient decreased with increasing load at $300{ }^{\circ} \mathrm{C}$, while it increased with the increase in applied load at $500{ }^{\circ} \mathrm{C}$. At $300^{\circ} \mathrm{C}$, severe abrasive wear characterized by grooves resulted in a high friction coefficient with $5 \mathrm{~N}$ applied, whereas the formation of a denser oxide layer consisting of $\mathrm{Cr}_{2} \mathrm{O}_{3}, \mathrm{FeCr}_{2} \mathrm{O}_{4}, \mathrm{Fe}_{2} \mathrm{O}_{3}$, etc., and the increased hardness caused by work hardening led to a decrease in friction characterized by mild adhesive wear. At $500{ }^{\circ} \mathrm{C}$, the transformation of $\mathrm{Fe}_{2} \mathrm{O}_{3}$ to the relatively softer $\mathrm{Fe}_{3} \mathrm{O}_{4}$ and the high production of lubricating $\mathrm{Mn}_{2} \mathrm{O}_{3}$ resulted in a minimum average friction coefficient (0.34) when $5 \mathrm{~N}$ was applied. However, the softening caused by high temperature weakened the hardening effect, and thus the friction coefficient increased with $15 \mathrm{~N}$ applied at $500{ }^{\circ} \mathrm{C}$.
\end{abstract}

Keywords: high-nitrogen austenitic stainless steel; wear; friction coefficient; high temperature

\section{Introduction}

High-nitrogen austenitic stainless steel (HNSS) can be used for non-magnetic drill collars in oil exploitation, bearing steels for automobile industry, and many other applications due to its excellent properties, i.e., high strength, good ductility, and superior corrosion resistance [1-6]. However, because of harsh service conditions, such as high temperature, heavy load, and high velocity, the demand for surface hardness and wear resistance is enhanced $[7,8]$. Investigations on preparation methods, mechanical properties, and corrosion resistance of HNSS have been widely carried out [9-12]. However, few reports about its tribological properties, especially at high temperatures, are available. Therefore, it is of great significance to investigate the friction and wear behaviors of HNSS at high temperature.

Wear at high temperature is a serious problem in many industrial applications, such as power generation, materials processing, and high-temperature bearing [13-15]. Metallic materials can be oxidized or softened at high temperature, which plays a significant role, causing a change in overall friction behavior [16]. This is because oxides can reduce metal 
wear by reducing or eliminating metal-metal contact, allowing a transition from severe to mild wear [17]. In addition, at elevated temperatures, the increasing dominance of dislocation climb, aided by increased lattice diffusion at high temperatures, results in a significant softening of metals $[18,19]$. Thus, the wear mechanism at high temperature is different from that at ambient temperature [20,21]. Hemant et al. [22] investigated the sliding friction and wear behaviors of austenitic stainless steel at a temperature of $473 \mathrm{~K}$ and $823 \mathrm{~K}$, respectively, and found serious damage at $823 \mathrm{~K}$ due to the softening of the rubbing surfaces. Wang et al. [23] evaluated the tribological behaviors of sodium carbonate coating on stainless steel at high temperatures, and the results suggested that the lubrication capability of NCO is partially due to the reconstruction of the oxide scale. The high-temperature wear mechanism of 445 stainless steel was studied, and the $\mathrm{Cr}$ rich oxide scale was able to stabilize the friction coefficient and reduce the wear rate [24]. In addition to temperature, the applied load also affects friction and wear behaviors at high temperature. Wang et al. [25] studied the effect of load on wear behavior at high temperature and found that the oxide layer at a higher load is easier to transfer onto the counterpart surface, leading to higher wear loss. Torres et al. [26] concluded that a higher applied load at high temperatures could lead to higher wear rates for the steels. Stott et al. [27] studied the effects of load on wear-protective layers during sliding at elevated temperatures, and the results showed that the layers were broken down, leading to enhanced wear damage, particularly at higher loads at 550 and $600{ }^{\circ} \mathrm{C}$. Additionally, Razali et al. [28] used a combination of numerical and experimental methods to reveal the relationship between tribological conditions and microstructural evolution. In addition, Lee et al. [29] used similar methods that revealed that the friction coefficient suddenly changes at critical surface strain, and the lubricant film loses its function when the surface strain of the material exceeds the critical surface strain.

At present, there is a lack of research on the tribological properties of HNSS at high temperatures, and the synergistic effects of load and temperature on the wear mechanisms of HNSS need to be further studied. In this work, high-temperature friction and wear tests under the conditions of $5 \mathrm{~N}$ at $300{ }^{\circ} \mathrm{C}, 15 \mathrm{~N}$ at $300{ }^{\circ} \mathrm{C}, 5 \mathrm{~N}$ at $500{ }^{\circ} \mathrm{C}$, and $15 \mathrm{~N}$ at $500{ }^{\circ} \mathrm{C}$ were applied on $\mathrm{HNSS}$ of $\mathrm{Fe}-19 \mathrm{Cr}-15 \mathrm{Mn}-0.66 \mathrm{~N}$. The microstructure and tribological properties of the samples were systematically characterized and analyzed.

\section{Experimental Details}

The material used in this study was Fe-19Cr-15Mn-0.66N HNSS. Its chemical composition is listed in Table 1. The material was cut into coupons with dimensions of $20 \mathrm{~mm} \times 20 \mathrm{~mm} \times 5 \mathrm{~mm}$. The samples were gradually ground using 2000\# SiC papers, then polished with a diamond paste of $2.5 \mu \mathrm{m}$, cleaned in ethanol, and finally dried using cool air.

Table 1. The chemical composition of the HNSS (wt $\%)$.

\begin{tabular}{ccccccccc}
\hline $\mathbf{C}$ & $\mathbf{S i}$ & $\mathbf{M n}$ & $\mathbf{P}$ & $\mathbf{S}$ & $\mathbf{C r}$ & $\mathbf{M o}$ & $\mathbf{N}$ & $\mathbf{F e}$ \\
\hline 0.044 & 0.24 & 15.80 & 0.017 & 0.005 & 18.40 & 2.19 & 0.66 & bal. \\
\hline
\end{tabular}

The wear tests were evaluated using a ball-on-disc tribometer (HTC-2, Lanzhou Zhongke Kaihua Technology Co., Ltd., Lanzhou, China). The ball and the disc were $\mathrm{Si}_{3} \mathrm{~N}_{4}$ and the HNSS, respectively. After installing the ball and disc in the holder on the tribometer, they were heated to the target temperatures of 300 and $500{ }^{\circ} \mathrm{C}$. The sliding tests were conducted under loads of $5 \mathrm{~N}$ and $15 \mathrm{~N}$ (yielding an initial Hertz peak contact pressure of 370-630 MPa) and were conducted continuously for a duration of $1800 \mathrm{~s}$ in air without lubrication. The samples were taken out immediately when the sliding tests ceased to prevent further oxidation. The morphologies of the wear tracks were observed using laser scanning confocal microscopy (LSCM, LEXT OLS400, Tokyo, Japan) and scanning electron microscopy (SEM, JEOL, JSM-6480, Takeno, Japan) under secondary electron image (SEI) mode at an accelerating voltage of $20 \mathrm{kV}$ and a probe current of $50 \mathrm{pA}$. The oxide layers 
formed on the wear tracks were characterized using energy-dispersive $X$-ray spectroscopy (EDS, X-Max 20, Oxford, UK) and X-ray photoelectron spectroscopy (XPS, ESCALAB 250Xi T, ThermoFisher Scientific, Waltham, MA, USA) using an Al $\mathrm{K} \alpha(1486.6 \mathrm{eV})$ radiation source. The analysis of the spectra was performed using CasaXPS software version 2.3.15 (CasaXPS Software Ltd.). The background baseline of all the signals was subtracted using a standard Shirley background line type. Before conducting curve fitting, all the peaks were calibrated by shifting C 1 s to $284.6 \mathrm{eV}$.

\section{Results}

\subsection{Friction Coefficient}

Figure 1 depicts the friction coefficient as a function of time for the HNSS under different test conditions. It is obvious that almost all the friction coefficient curves exhibited a similar tendency under all the four test conditions with the increase in time. Indeed, the curves could be divided into two stages, as can be seen from Figure 1. The curves of the friction coefficient dropped dramatically in the initial stage for the first $400 \mathrm{~s}$ and then rose up slowly without significant fluctuations or maintained a relatively stable trend as the time increased.

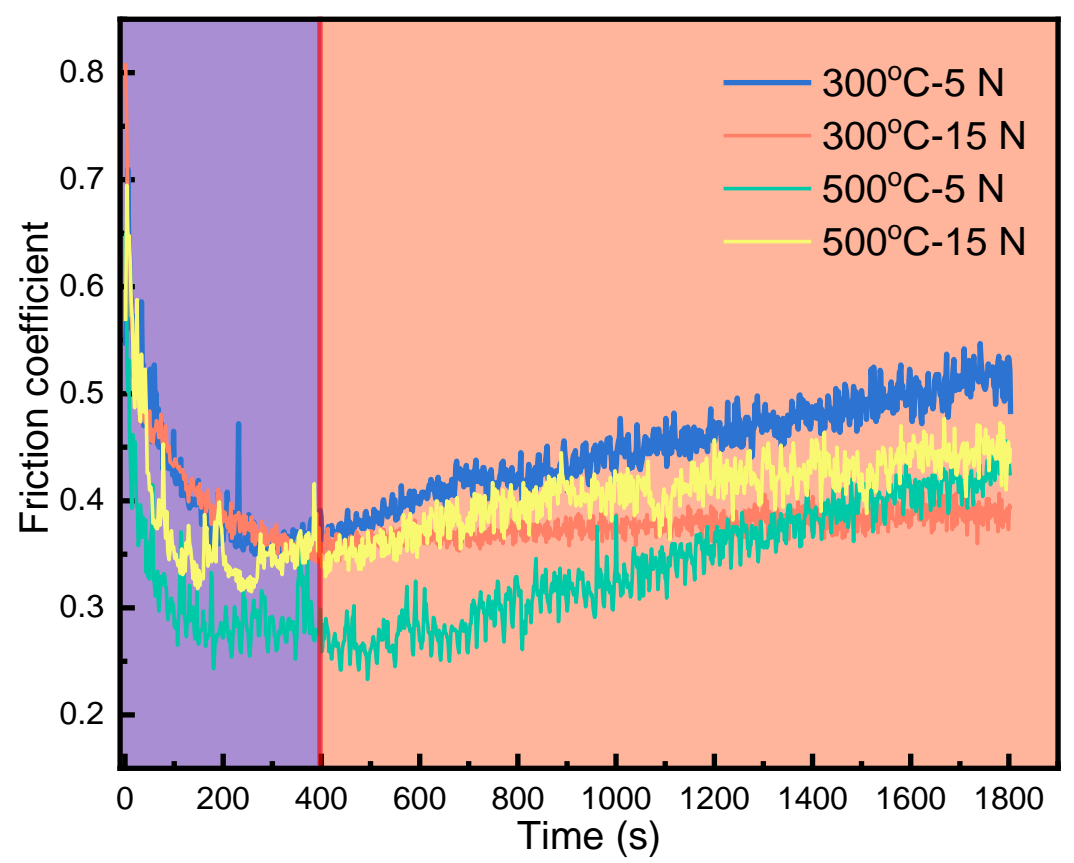

Figure 1. Friction coefficients of the HNSS under different conditions.

To observe the magnitude of the friction coefficient under different conditions more visually, the average friction coefficients of all four test conditions are shown in Figure 2. When the samples were tested at $300{ }^{\circ} \mathrm{C}$, the average friction coefficients obtained by applying $5 \mathrm{~N}$ and $15 \mathrm{~N}$ were 0.44 and 0.38 , respectively, indicating that the change in the friction coefficient is directly related to the applied load [30]. When the test temperature was $500{ }^{\circ} \mathrm{C}$, the average friction coefficients obtained by applying $5 \mathrm{~N}$ and $15 \mathrm{~N}$ were 0.34 and 0.40 , respectively. The variation in the friction coefficient shows an interesting phenomenon. When the HNSS was tested at $300^{\circ} \mathrm{C}$, its friction coefficient decreased with increasing load but showed an inverse trend when the temperature was $500{ }^{\circ} \mathrm{C}$. This will be further explained in the Discussion section. 


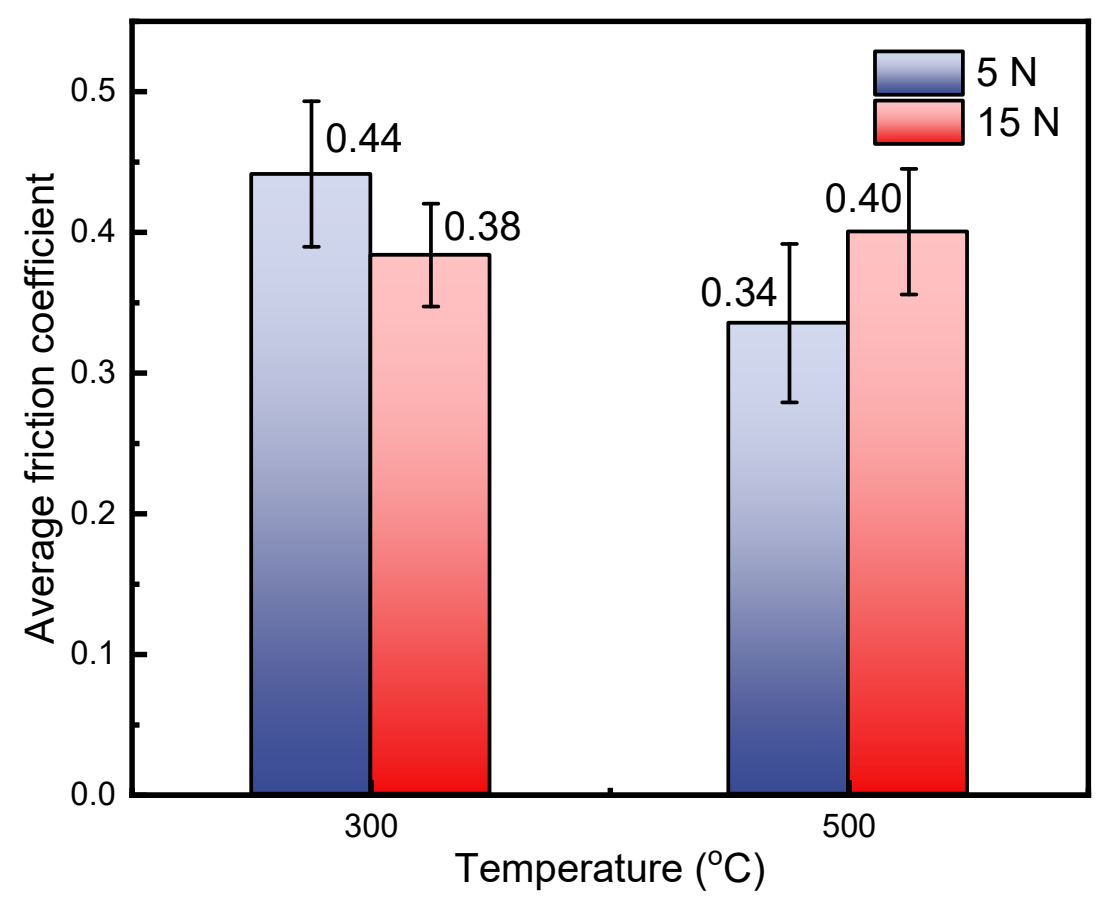

Figure 2. Average friction coefficients of the HNSS under different conditions.

\subsection{LSCM of the Wear Tracks}

Figure 3 shows the LSCM diagrams of the wear tracks. It can be seen that the surfaces of the wear tracks were seriously damaged. Grooves and oxide layers (dark zone) were observed on the surfaces of the wear tracks under all four conditions. As shown in Figure $3 \mathrm{a}$, the width of the wear track was about $480 \mu \mathrm{m}$, and the oxide layer on the surface of the wear track was discontinuous when $5 \mathrm{~N}$ was applied at $300^{\circ} \mathrm{C}$. When the load was changed to $15 \mathrm{~N}$, the morphology of the wear track was similar to that at $5 \mathrm{~N}$, except that the width of the wear track increased to $682 \mu \mathrm{m}$, as shown in Figure $3 \mathrm{~b}$. At $500{ }^{\circ} \mathrm{C}$, the worn surface was almost completely covered by the oxide layer, and the width of the wear track was about $423 \mu \mathrm{m}$ with $5 \mathrm{~N}$ applied. When $15 \mathrm{~N}$ was applied at $500{ }^{\circ} \mathrm{C}$ (Figure $3 \mathrm{~d}$ ), the width of the wear track increased to $683 \mu \mathrm{m}$, and there were a large number of grooves as well as delamination of oxide on the surface.

\subsection{Morphologies of the Wear Tracks}

Figure 4 shows the SEM morphologies of the wear tracks for the HNSS under different conditions. It could be found that the surface was rough when $5 \mathrm{~N}$ was applied at $300{ }^{\circ} \mathrm{C}$. The micrograph of the wear track showed a variety of superficial damages, such as grooves and stripping areas. The material near the grooves was subjected to severe plastic deformation and plastic damage, which subsequently formed the wear debris [31], which potentially acted as a third-body abrasive source, resulting in severe abrasive wear. When the load was increased to $15 \mathrm{~N}$, the morphology of the wear track was as can be seen in Figure $4 \mathrm{~b}$. Some small particles and stripping areas could be found. Meanwhile, work hardening caused by dislocation accumulation occurred due to the increased load, resulting in an increase in hardness [5,32-35]. Thus, the wear resistance of the sample was better than that of the sample with $5 \mathrm{~N}$ applied at the same temperature. 

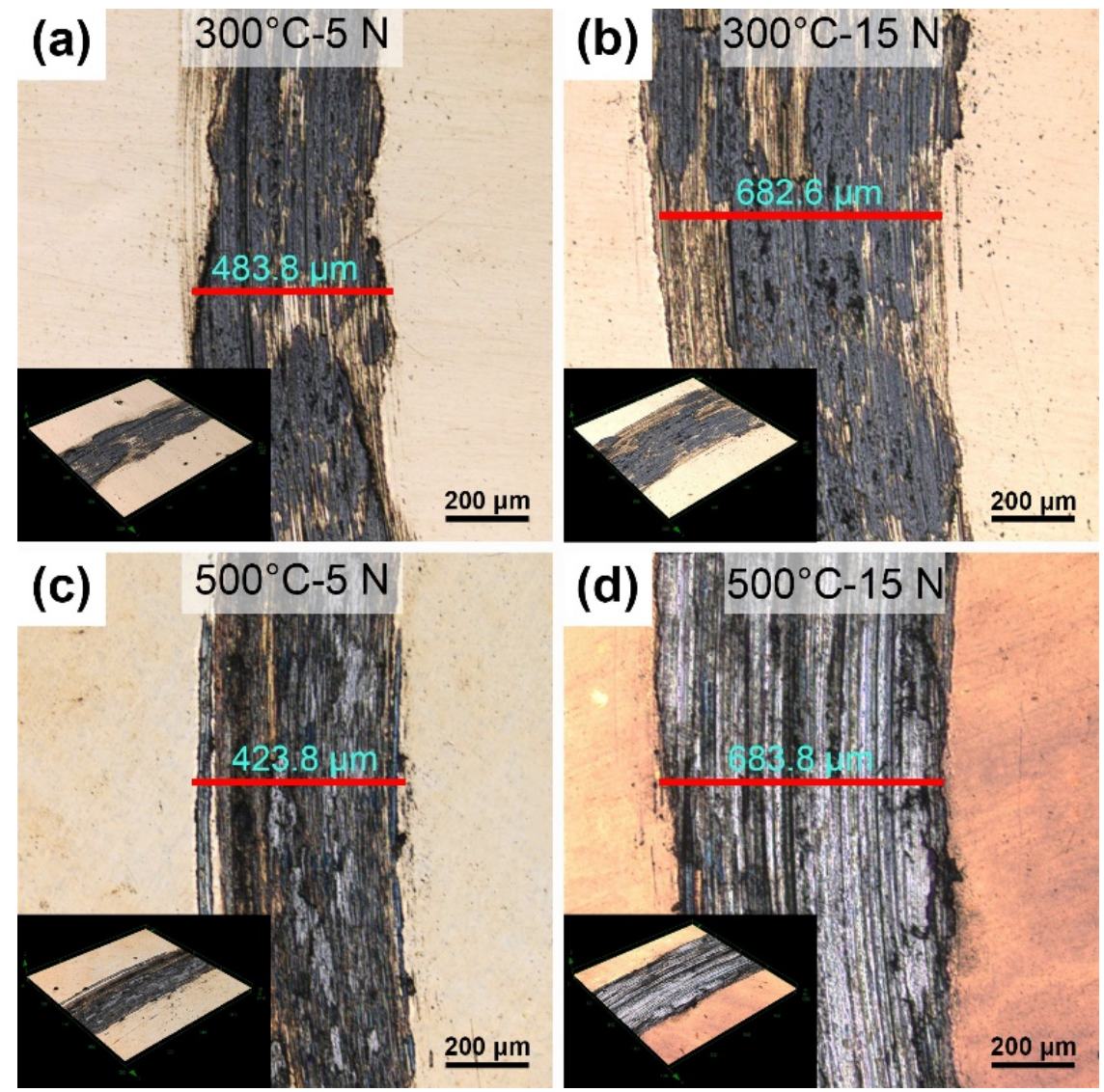

Figure 3. Morphologies of wear tracks for the HNSS under different conditions: (a) $300{ }^{\circ} \mathrm{C}-5 \mathrm{~N}$, (b) $300{ }^{\circ} \mathrm{C}-15 \mathrm{~N}$, (c) $500{ }^{\circ} \mathrm{C}-5 \mathrm{~N}$, and (d) $500{ }^{\circ} \mathrm{C}-15 \mathrm{~N}$.
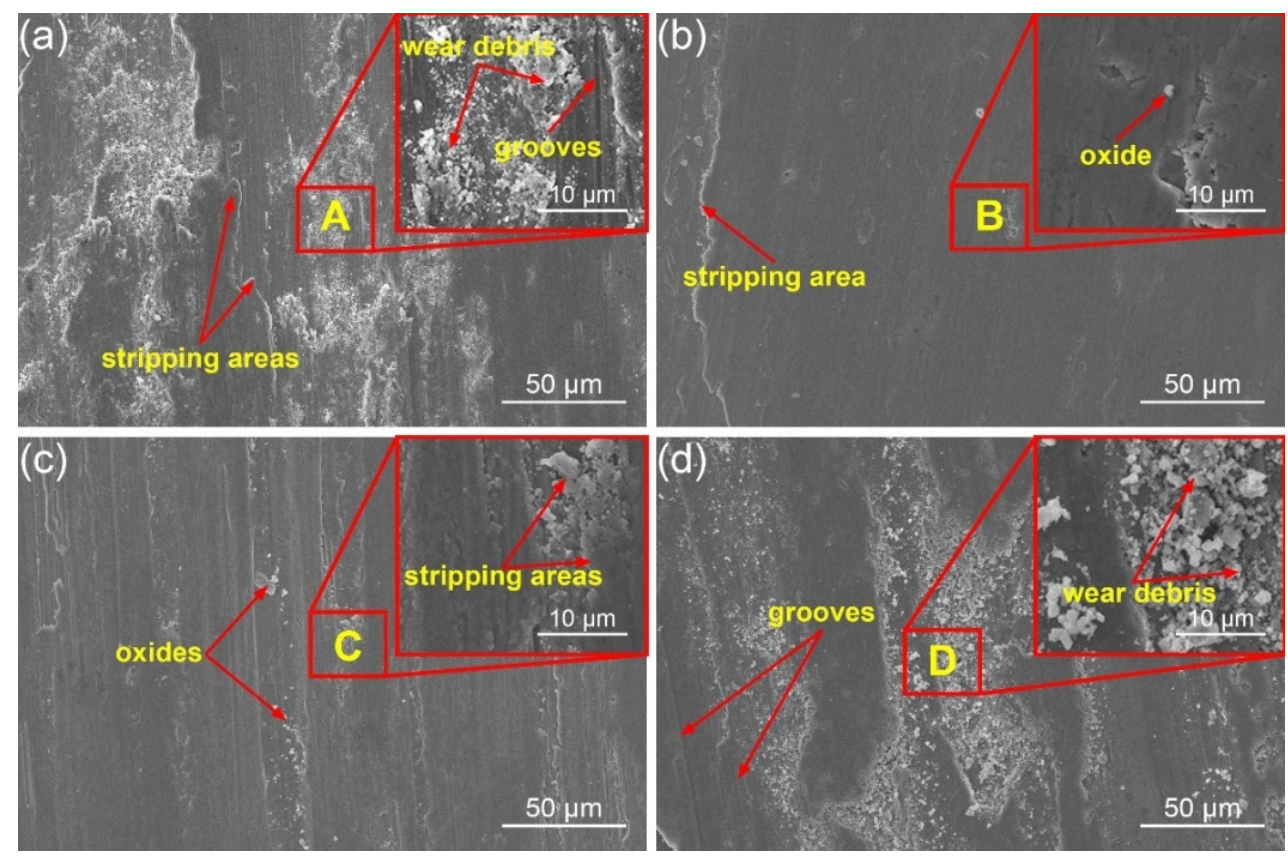

Figure 4. Wear track microstructure of samples under different conditions: (a) $300{ }^{\circ} \mathrm{C}-5 \mathrm{~N}$, (b) $300{ }^{\circ} \mathrm{C}-15 \mathrm{~N},\left(\right.$ c) $500{ }^{\circ} \mathrm{C}-5 \mathrm{~N}$, and (d) $500{ }^{\circ} \mathrm{C}-15 \mathrm{~N}$.

Figure $4 \mathrm{c}$ shows the micrograph of the wear track when $5 \mathrm{~N}$ was applied at $500{ }^{\circ} \mathrm{C}$. It is shown that the worn surface was relatively smooth. However, some shallow grooves along the sliding direction could still be seen, which was mainly caused by wear debris 
under dry-friction conditions. Local stripping areas could also be seen on the surface. Figure $4 \mathrm{~d}$ shows the surface of the wear track when $15 \mathrm{~N}$ was applied at $500{ }^{\circ} \mathrm{C}$; a large number of wear debris and some grooves could obviously be seen on the surface, which showed relatively serious wear behavior.

\subsection{Microstructure Characteristics of the Wear Tracks}

The SEM morphologies and corresponding distributions of elements on the worn surfaces of the HNSS are shown in Figure 5. It is obvious that the O element was distributed in the wear tracks of all conditions, indicating that the samples were oxidized at both $300^{\circ} \mathrm{C}$ and $500{ }^{\circ} \mathrm{C}$. It can be found from the EDS mapping that the oxide layers mainly consisted of the elements $\mathrm{Fe}, \mathrm{Cr}, \mathrm{Mn}$, and $\mathrm{O}$. Although there was no obvious change in the distribution of elements, a more serious discontinuous distribution could be observed on the oxide layer at $300{ }^{\circ} \mathrm{C}$, which was consistent with the results of LSCM, indicating an oxidationscratch-reoxidation mechanism in the process of friction [36]. It could also be found that oxidation was more severe with increasing temperature, and this was demonstrated by the distribution of the $\mathrm{O}$ element, which was distributed from being mainly present in the wear track at $300{ }^{\circ} \mathrm{C}$ to also being significantly distributed on the substrate at $500{ }^{\circ} \mathrm{C}$.
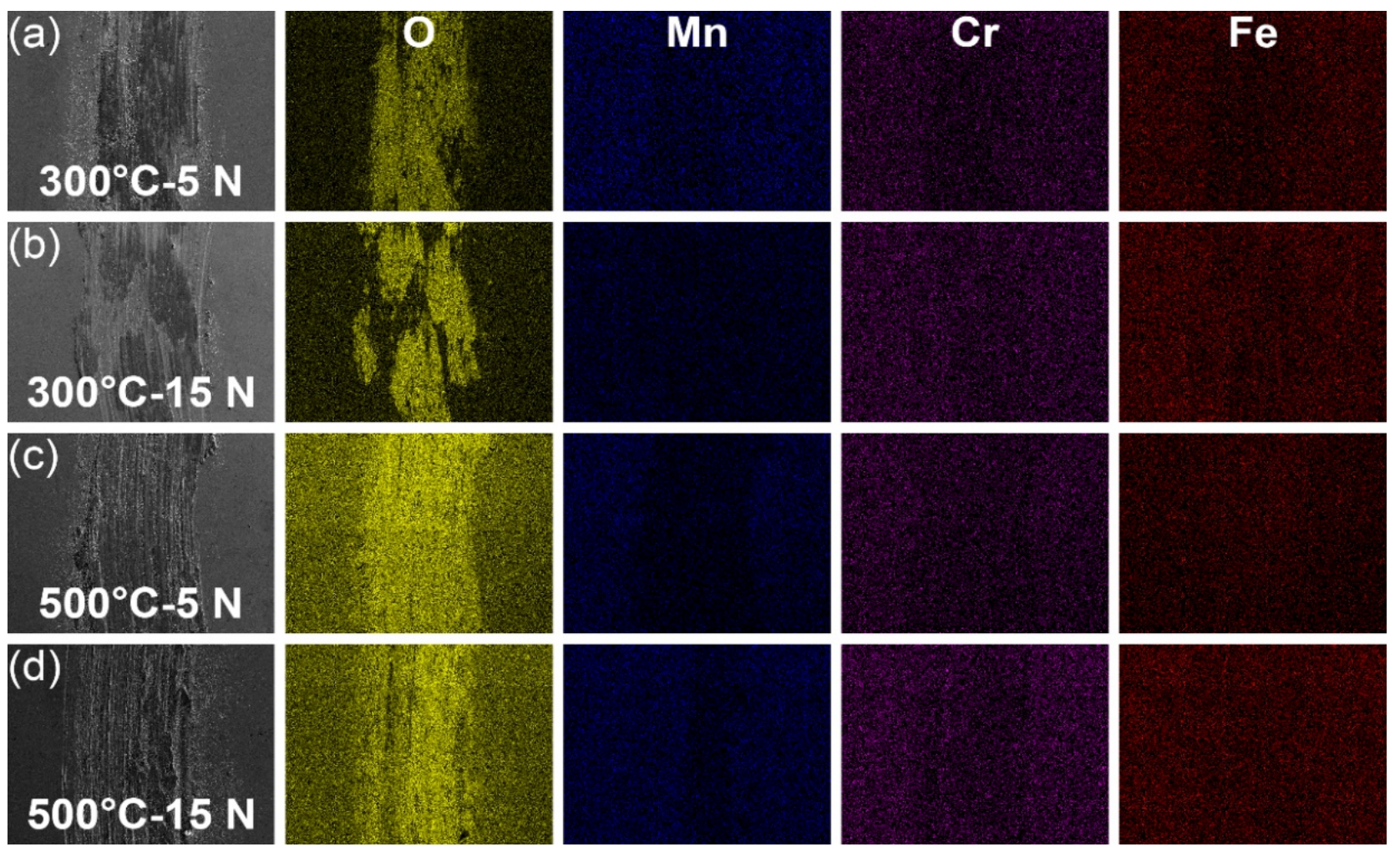

Figure 5. SEM morphologies of worn surfaces and corresponding element mapping: (a) $300{ }^{\circ} \mathrm{C}-5 \mathrm{~N},(\mathbf{b}) 300{ }^{\circ} \mathrm{C}-15 \mathrm{~N}$, (c) $500{ }^{\circ} \mathrm{C}-5 \mathrm{~N}$, and (d) $500{ }^{\circ} \mathrm{C}-15 \mathrm{~N}$.

XPS was used to investigate the components of oxide layers on the worn surfaces under different conditions. Figure 6 presents the XPS spectra of the oxide layers. The peaks of Fe 2p, Mn 2p, Cr 2p, and O 1s were found in all the survey spectra. In addition, the intensity of $\mathrm{Cr} 2 \mathrm{p}$ dropped obviously when the temperature increased to $500{ }^{\circ} \mathrm{C}$, while the intensity of Mn 2p showed a slight increase. 


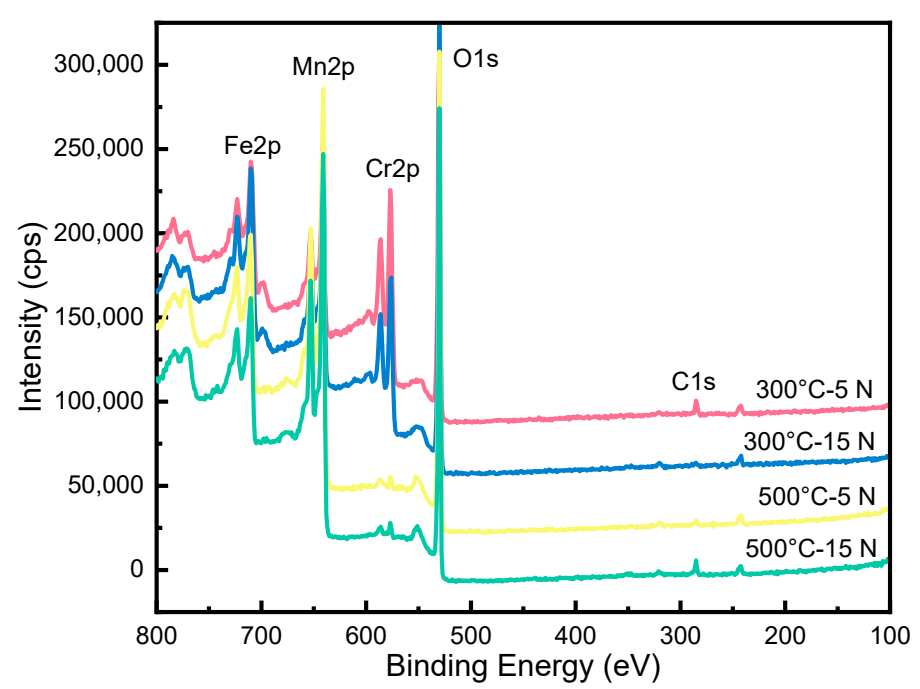

Figure 6. XPS spectra of oxide layers at wear tracks for the HNSS under different conditions.

The high-resolution XPS spectra of Fe 2p of the wear tracks under different conditions are shown in Figure 7. The element of Fe has two common oxidation states, ferrous $\left(\mathrm{Fe}^{2+}\right)$ and ferric $\left(\mathrm{Fe}^{3+}\right)$ [37], and the two oxidation states exist under all conditions. The binding energy (BE) of $\mathrm{Fe}^{3+}(2 \mathrm{p} 3 / 2)$ in $\mathrm{Fe}_{2} \mathrm{O}_{3}$ and $\mathrm{Fe}^{2+}(2 \mathrm{p} 3 / 2)$ in $\mathrm{Fe}_{3} \mathrm{O}_{4}$ was $711.6 \mathrm{eV}$ and $709.2 \mathrm{eV}$, respectively [38,39]. The peak of metallic $\mathrm{Fe}^{0}(2 \mathrm{p} 3 / 2)$ was located at $706.6 \mathrm{eV}$ [40]. It can be concluded from Figure 7 that $\mathrm{Fe}$ is mainly present in the above three forms under different conditions, with $\mathrm{Fe}_{2} \mathrm{O}_{3}$ and $\mathrm{Fe}_{3} \mathrm{O}_{4}$ in all cases. However, metallic Fe could only be detected at $300{ }^{\circ} \mathrm{C}$, indicating more severe oxidation with increasing temperature, which is also consistent with the result in Figure 5.
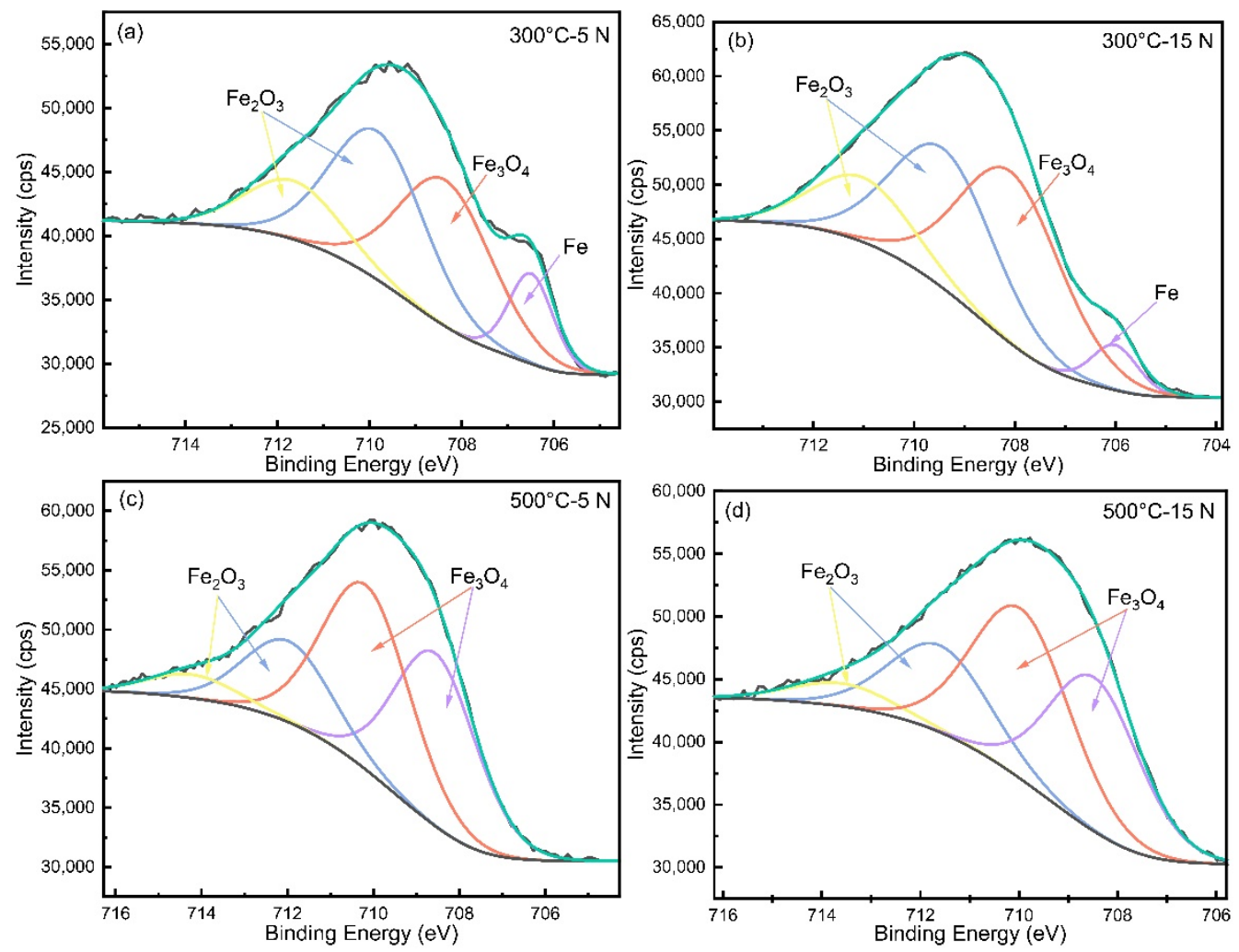

Figure 7. Spectra of Fe $2 \mathrm{p}$ of wear tracks under different conditions. (a) $300^{\circ} \mathrm{C}-5 \mathrm{~N}$, (b) $300{ }^{\circ} \mathrm{C}-15 \mathrm{~N}$, (c) $500{ }^{\circ} \mathrm{C}-5 \mathrm{~N}$, and (d) $500{ }^{\circ} \mathrm{C}-15 \mathrm{~N}$. 
The high-resolution XPS spectra of $\mathrm{Cr} 2 \mathrm{p}$ of the wear tracks under different conditions are shown in Figure 8. The BE of $\mathrm{Cr}^{3+}(2 \mathrm{p} 3 / 2)$ in $\mathrm{Cr}_{2} \mathrm{O}_{3}$ was $576.4 \mathrm{eV}$ [41], and a peak at $\sim 2.6 \mathrm{eV}$ lower than the $\mathrm{Cr}^{3+}(2 \mathrm{p} 3 / 2)$ peak was observed, which was attributed to the $\mathrm{BE}$ of metallic $\mathrm{Cr}^{0}[42,43] . \mathrm{FeCr}_{2} \mathrm{O}_{4}$ with a BE of $577.9 \mathrm{eV}$ could also be detected at $300{ }^{\circ} \mathrm{C}$ [38]. However, there only existed $\mathrm{Cr}_{2} \mathrm{O}_{3}$ on the wear tracks at $500{ }^{\circ} \mathrm{C}$, as seen in Figure 8 .
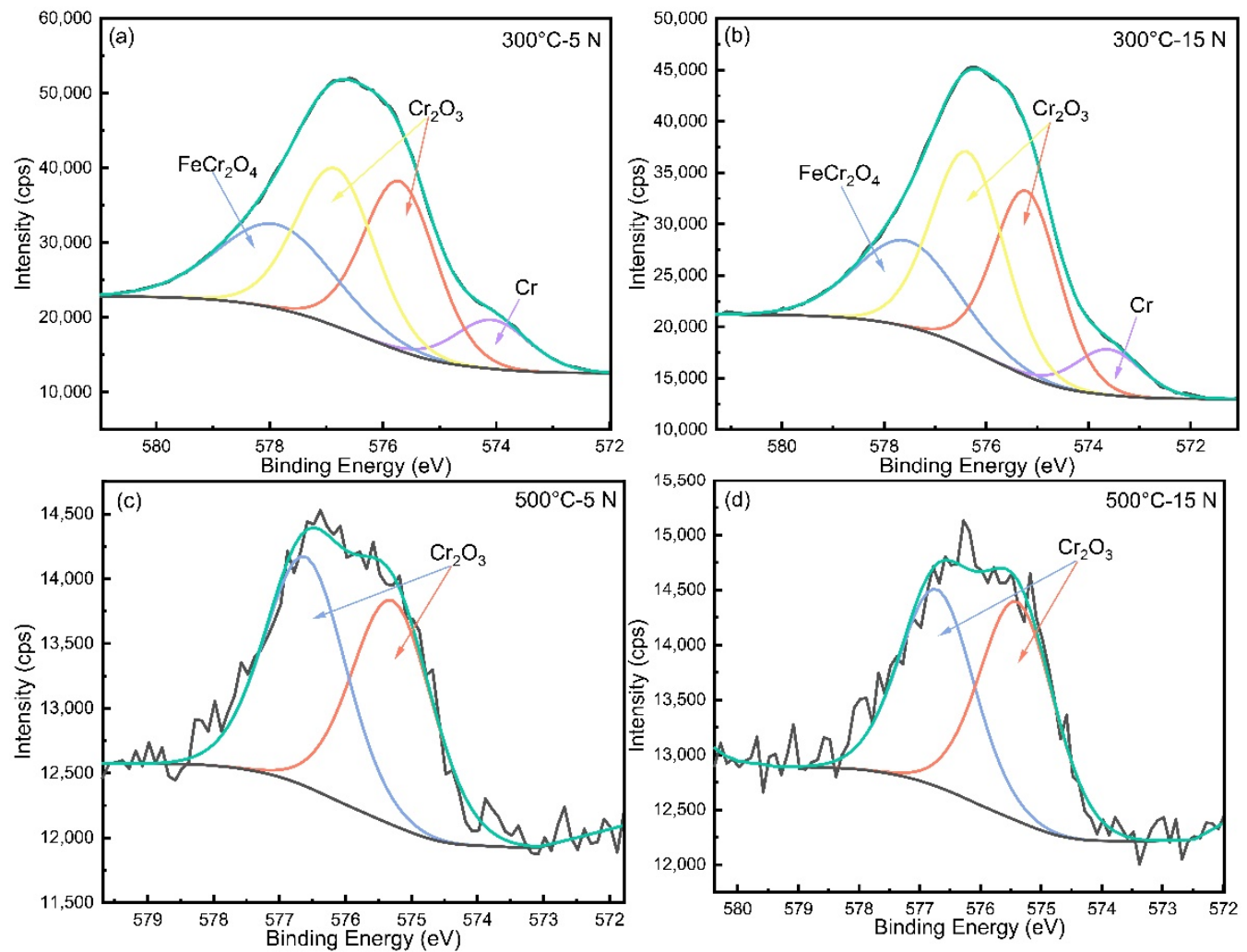

Figure 8. Spectra of $\mathrm{Cr} 2 \mathrm{p}$ of wear tracks under different conditions. (a) $300{ }^{\circ} \mathrm{C}-5 \mathrm{~N},(\mathbf{b}) 300{ }^{\circ} \mathrm{C}-15 \mathrm{~N}$, (c) $500{ }^{\circ} \mathrm{C}-5 \mathrm{~N}$, and (d) $500{ }^{\circ} \mathrm{C}-15 \mathrm{~N}$.

The high-resolution XPS spectra of Mn 2p of the wear tracks under different conditions are shown in Figure 9. The binding energy (BE) of $\mathrm{Mn}^{3+}(2 \mathrm{p} 3 / 2)$ in $\mathrm{Mn}_{2} \mathrm{O}_{3}$ and $\mathrm{Mn}^{2+}$ $(2 \mathrm{p} 3 / 2)$ in $\mathrm{MnO}$ was $641.9 \mathrm{eV}$ and $643.2 \mathrm{eV}$, respectively [38,39]. The peak of metallic $\mathrm{Mn}^{0}$ (2p3/2) was located at $639.6 \mathrm{eV}$ [38]. In addition, the above three states of Mn were present under all four conditions.

Figure 10 shows the contents of $\mathrm{Fe}, \mathrm{Mn}$, and $\mathrm{Cr}$ oxides under different conditions based on the results of XPS. It could be observed that the composition of the oxides changed significantly with the change in the test conditions. When the temperature was $300^{\circ} \mathrm{C}$, the oxides of $\mathrm{Cr}$ were the most abundant among the oxides, while they decreased significantly when the temperature increased to $500{ }^{\circ} \mathrm{C}$, which could also be proved by the survey spectra. In addition, the oxides content of $\mathrm{Mn}$ increased significantly with increasing temperature. Although the oxide content of Fe also increased at high temperatures, the increase was not as great as that of $\mathrm{Mn}$. 

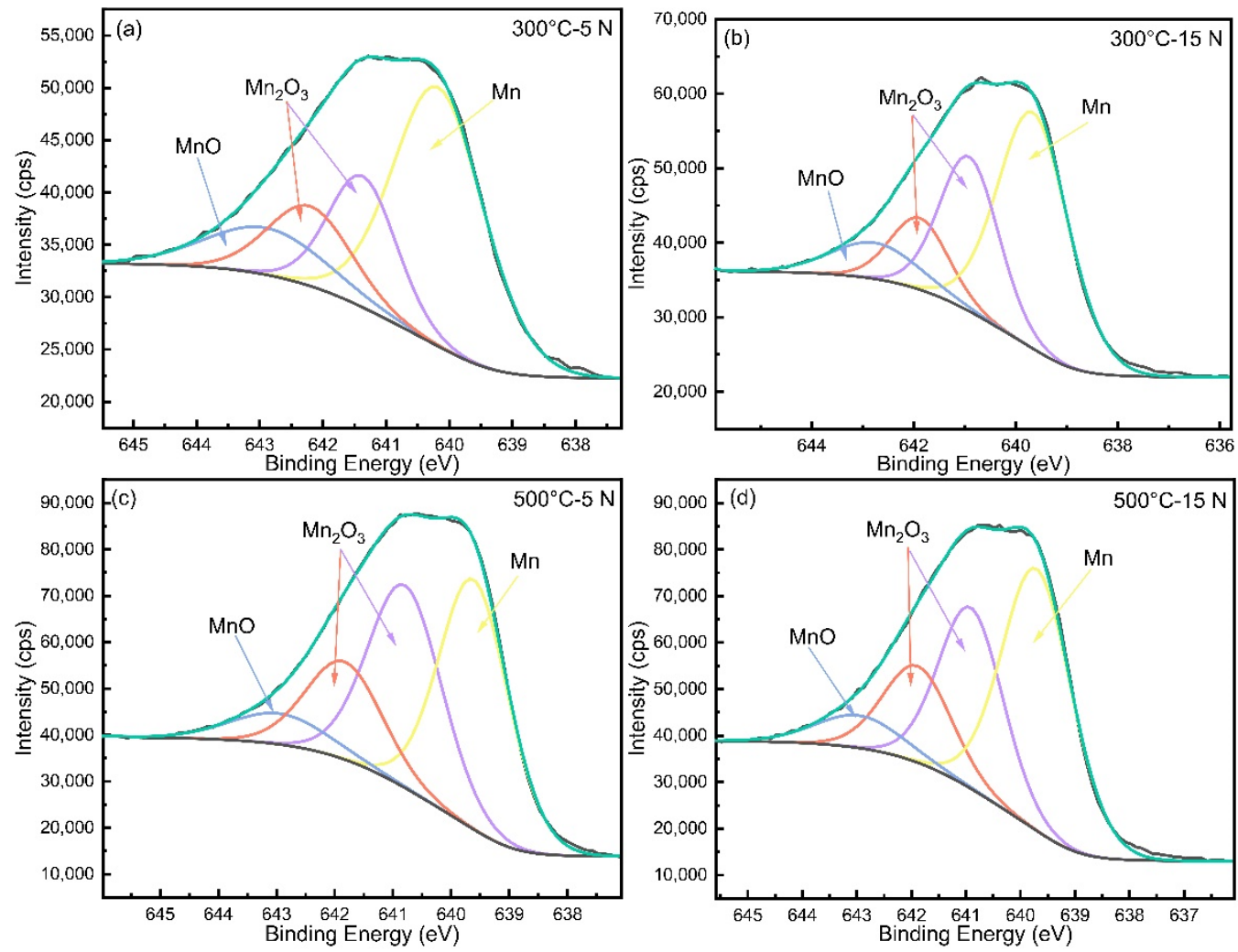

Figure 9. Mn 2p spectra of wear tracks under different conditions. (a) $300{ }^{\circ} \mathrm{C}-5 \mathrm{~N}$, (b) $300{ }^{\circ} \mathrm{C}-15 \mathrm{~N}$, (c) $500{ }^{\circ} \mathrm{C}-5 \mathrm{~N}$, and (d) $500{ }^{\circ} \mathrm{C}-15 \mathrm{~N}$.

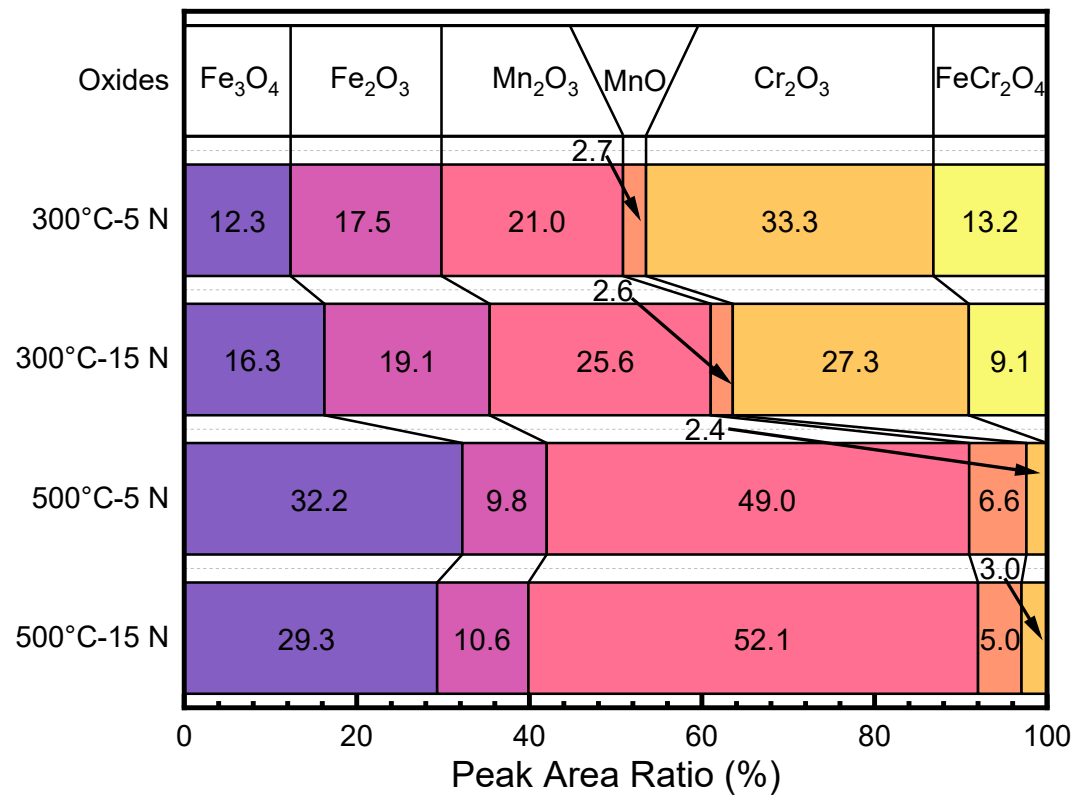

Figure 10. Contents of oxides under different conditions.

\section{Discussion}

The friction coefficient curves show some significant variations in trends and values under different conditions. Detailed studies of the wear tracks have shown that these changes are associated with the oxide layers formed on the wear surfaces. Oxidation wear is a common phenomenon in a high-temperature environment, characterized by the presence of an oxide layer on the sliding surface [44,45]. The surfaces of the samples are easily oxidized under high temperature due to the high affinity of $\mathrm{Cr}, \mathrm{Mn}$, and $\mathrm{Fe}$ to 
$\mathrm{O}[23,24]$. These oxides usually became wear particles due to the normal stress and shear force from the friction couple during the friction test, and the wear particles, which act as a third body, often plough the wear tracks as the sliding develops, resulting in a fluctuation of the friction coefficient and a relatively high value [16]. After the generation of debris particles, some are lost from between the surfaces, while most are retained and they are involved in the development of a compact oxide layer [23]. This layer can provide wear protection for long periods due to its high smooth and hardness, resulting in a decrease in the friction coefficient. The development of this layer from the agglomeration and compaction of the wear debris particles is described elsewhere [46].

As is seen, oxide layers were formed on the surfaces of all wear tracks (Figures 3 and 4), but the stability of the oxide layers was different under different conditions. In general, this compact oxide layer can form at a temperature higher than $150{ }^{\circ} \mathrm{C}$ [16]. In addition, the rate of establishment of this layer usually increases with the increase in temperature [17], which can explain the phenomenon that the friction coefficients at $500{ }^{\circ} \mathrm{C}$ were lower than those at $300{ }^{\circ} \mathrm{C}$ for the first $400 \mathrm{~s}$. It can be seen from the results of the friction coefficient that there was no significant fluctuation after $400 \mathrm{~s}$ (Figure 1), indicating that the oxides formed on the wear track surface play a crucial role in the wear process. However, there existed a little difference in the friction coefficient trend after $400 \mathrm{~s}$. Most of them increased slowly as the time increased, except for the curve of $300{ }^{\circ} \mathrm{C}-15 \mathrm{~N}$, which maintained a relative constant at 0.38 . After the establishment of the compact oxide layer, there were two competitive processes, breakdown and reconsolidation of this layer, indicating that the layer established at $300{ }^{\circ} \mathrm{C}$ with $15 \mathrm{~N}$ applied may be the most stable one.

When a load of $5 \mathrm{~N}$ was applied at $300{ }^{\circ} \mathrm{C}$, an oxide layer consisting of $\mathrm{Fe}_{2} \mathrm{O}_{3}, \mathrm{Fe}_{3} \mathrm{O}_{4}$, $\mathrm{Cr}_{2} \mathrm{O}_{3}, \mathrm{FeCr}_{2} \mathrm{O}_{4}, \mathrm{MnO}$, and $\mathrm{Mn}_{2} \mathrm{O}_{3}$ was formed on the wear track, which can be concluded from the results of EDS and XPS. It can be revealed that the content of $\mathrm{Cr}_{2} \mathrm{O}_{3}$ is higher than XPS (Figures 6 and 10), and it is usually used as the third body to grind the surface of the wear tracks due to its high hardness [24]. Thus, severe abrasive wear occurred at this time. In addition, part of the $\mathrm{Cr}_{2} \mathrm{O}_{3}$ can react easily with $\mathrm{Fe}$ to form $\mathrm{FeCr}_{2} \mathrm{O}_{4}$ at $300{ }^{\circ} \mathrm{C}$ [47], which has high hardness and can be easily removed from the surface during the process of friction, thus greatly reducing the protective ability of the oxide layer [37,48]. With the plowing of $\mathrm{Cr}_{2} \mathrm{O}_{3}$, the transformation of $\mathrm{Cr}_{2} \mathrm{O}_{3}$ to $\mathrm{FeCr}_{2} \mathrm{O}_{4}$ and the long-term shear action of the friction couple, the layer was destroyed, which resulted in the exposure of the matrix and the formation of a large amount of wear debris on the surface of the wear track (Figure 4a) [37]. The HNSS matrix was ploughed by hard debris under the extrusion of the friction couple, forming some grooves parallel to the sliding direction on the surface. Thus, the friction coefficient increased continuously and the average friction coefficient (0.44) was the highest under this condition with the wear mechanism of oxidation wear and severe abrasive wear [49].

The addition of the $\mathrm{N}$ element could further reduce the stacking fault energy of austenitic stainless steel, which increased the ability of work hardening. When $15 \mathrm{~N}$ was applied at $300{ }^{\circ} \mathrm{C}$, the increased load facilitated plastic deformation of the HNSS, which led to an increase in the dislocation density and an increment in the dislocation, resulting in the effect of work hardening and the improvement of the hardness of the matrix [5]. A material with higher hardness usually shows a lower friction coefficient to that of a material with lower hardness [50-53]. The higher load also makes it easier to crush oxide particles, such as $\mathrm{Cr}_{2} \mathrm{O}_{3}$, which are usually squeezed into previously formed grooves, which in turn makes the formed compact layer denser and also enhances the load-bearing capacity $[17,54]$. During the period of $0 \sim 400 \mathrm{~s}$ of the test, the curve of the friction coefficient was almost coincident with that at $300{ }^{\circ} \mathrm{C}-5 \mathrm{~N}$, but it became much more stable after $400 \mathrm{~s}$ due to the increased hardness and compact oxide layer (Figure 1). At this time, a significant reduction in the content of $\mathrm{Cr}_{2} \mathrm{O}_{3}$ and $\mathrm{FeCr}_{2} \mathrm{O}_{4}$ also occurred, and the grinding effect on the surface was reduced. However, a partial oxide layer may peel off and adhere to the surface of the friction couple during friction due to shear action and the accumulation of plastic deformation in the contact area. The peeling oxide layer was then gradually 
removed from the surface, and the exposed metal matrix under the stripping area was oxidized to form a new oxide layer (Figure 5b). The exfoliated oxidation products hindered direct contact between the friction couple and the matrix. The effects of increased hardness, the formation of a denser oxide layer, and the exfoliated oxidation products under this condition make the HNSS have better wear resistance than that of $300{ }^{\circ} \mathrm{C}-5 \mathrm{~N}$, showing the wear mechanism of oxidation wear and mild adhesive wear and forming a stable friction state (Figure 1).

When a load of $5 \mathrm{~N}$ was applied at $500{ }^{\circ} \mathrm{C}$, only a few oxide particles, shallow grooves, and sporadic stripping areas could be observed, as seen in Figure 4c. It could also be found that the content of $\mathrm{Cr}$ oxides was significantly reduced, and $\mathrm{Cr}_{2} \mathrm{O}_{3}$ had the effect of inhibiting the diffusion of $\mathrm{O}$ to the inside. Thus, a large amount of Fe and Mn oxides were formed when $\mathrm{Cr}_{2} \mathrm{O}_{3}$ was reduced. Among them, Mn has a stronger affinity with $\mathrm{O}$ compared to $\mathrm{Fe}$, so the oxides of $\mathrm{Mn}$, i.e., $\mathrm{MnO}$ and $\mathrm{Mn}_{2} \mathrm{O}_{3}$, are more abundant $[23,24]$. The latter, in particular, is generated in large quantities and is beneficial for lubrication during friction [55]. In addition, at $500{ }^{\circ} \mathrm{C}, \mathrm{Fe}_{2} \mathrm{O}_{3}$ is easily transformed into $\mathrm{Fe}_{3} \mathrm{O}_{4}$, which has lower hardness than $\mathrm{Fe}_{2} \mathrm{O}_{3}$, and also plays a certain protective effect $[24,56]$. Additionally, the oxide layer is softened due to the high temperature, which can reduce friction to some extent $[38,57,58]$. Due to the accumulation of plastic deformation, the partial layer peeled off and adhered to the friction couple. Therefore, the friction process mainly occurred between the oxides and the friction couple, which could play a better role in tribological properties [59-61], and the average friction coefficient (0.34) was the smallest under this condition in all cases (Figure 2) [62,63].

When a load of $15 \mathrm{~N}$ was applied at $500{ }^{\circ} \mathrm{C}$, the composition of the oxide layer did not change much compared to that at $500{ }^{\circ} \mathrm{C}-5 \mathrm{~N}$, while the increased temperature softened the matrix, resulting in the weakening of work hardening [64]. In addition, the wear of the oxide layer was aggravated and the layer was destroyed due to the increased load, leading to large amounts of wear debris and some grooves (Figures $3 \mathrm{~d}$ and $4 \mathrm{~d}$ ), showing typical abrasive wear. The increase in Mn content on the wear track of EDS indicated that the compacted oxide layer on the surface was slightly damaged, which led to an increase in the friction coefficient (0.40) [26], so the wear resistance weakened. However, the oxide layer still played a certain role in protection, so the wear resistance at this time was better than that at $300{ }^{\circ} \mathrm{C}$ with $5 \mathrm{~N}$ applied. The wear mechanism of the HNSS under this condition was mainly oxidation wear and severe abrasive wear.

\section{Summary}

The friction and wear behaviors of the Fe-19Cr-15Mn-0.66N HNSS at high temperature were tested under different conditions with different loads and temperatures, and the conclusions can be drawn as follows:

(1). The friction coefficient of HNSS decreased with time up to $400 \mathrm{~s}$ but rose up slowly or maintained a relatively stable trend as the time increased. The average friction coefficient decreased with increasing load at $300^{\circ} \mathrm{C}$, while it showed a reverse trend at $500{ }^{\circ} \mathrm{C}$, which depended on the wear mechanism that reflects the competitive processes, including breakdown and reconsolidation of the oxide layer formed on wear tracks.

(2). At $300{ }^{\circ} \mathrm{C}$, the friction coefficient curve of HNSS with $15 \mathrm{~N}$ applied showed a stable friction state after $400 \mathrm{~s}$ due to the formation of a denser oxide layer consisting of $\mathrm{Cr}_{2} \mathrm{O}_{3}$, $\mathrm{Fe}_{2} \mathrm{O}_{3}$, and $\mathrm{Mn}_{2} \mathrm{O}_{3}$ and increased hardness caused by work hardening, showing the wear mechanisms of oxidation wear and adhesive wear.

(3). Under the conditions of $500{ }^{\circ} \mathrm{C}-5 \mathrm{~N}$, softening at high temperature and the production of large amounts of $\mathrm{Mn}_{2} \mathrm{O}_{3}$, which has a lubricating effect, minimized the friction of the sample, showing the lowest friction coefficient with a value of 0.34 . In addition, the increased temperature also weakened the work hardening, resulting in severe abrasive wear at $500{ }^{\circ} \mathrm{C}-15 \mathrm{~N}$. 
Author Contributions: Conceptualization, Y.Q. and Z.Z.; methodology, J.C.; software, X.W.; validation, S.S., H.Z. and L.Y.; formal analysis, S.S.; investigation, H.Z.; data curation, S.S.; writing-original draft preparation, S.S., H.Z. and H.Y.; writing-review and editing, Y.Q. and Z.Z.; supervision, J.Z.; and funding acquisition, D.W., Z.L. and J.L. All authors have read and agreed to the published version of the manuscript.

Funding: This research received no external funding.

Institutional Review Board Statement: Not applicable.

Informed Consent Statement: Not applicable.

Data Availability Statement: The data used to support the findings of this study are available from the corresponding author upon request.

Acknowledgments: This work is funded by the National Natural Science Foundation of China (nos. 51905110 and 52005228), the Guangdong Province Key Area R\&D Program (2020B010184001), and the Science Foundation of Jiangsu Province (BK 20180984).

Conflicts of Interest: The authors declare no conflict of interest.

\section{References}

1. Zhang, X.R.; Sun, S.C.; Sun, G.X.; Han, S.; Jiang, Z.H.; Lian, J.S. Nanoindentation creep deformation behaviour of high nitrogen nickel-free austenitic stainless steel. Mater. Sci. Technol. 2019, 35, 1592-1599. [CrossRef]

2. Li, J.G.; Li, H.; Peng, W.; Xiang, T.; Xu, Z.Y.; Yang, J.C. Effect of simulated welding thermal cycles on microstructure and mechanical properties of coarse-grain heat-affected zone of high nitrogen austenitic stainless steel. Mater. Charact. 2019, 149, 206-217. [CrossRef]

3. Vats, V.; Baskaran, T.; Arya, S.B. Tribo-corrosion study of nickel-free, high nitrogen and high manganese austenitic stainless steel. Tribol. Int. 2018, 119, 659-666. [CrossRef]

4. Qiao, Y.X.; Wang, X.Y.; Chen, J.; Yang, L.L.; Wang, X.J.; Zhou, H.L.; Zou, J.S. Electrochemical behavior and passive film composition of a high-nitrogen nickel-free austenitic stainless steel. Arab. J. Sci. Eng. 2021, 1-8. [CrossRef]

5. Qiao, Y.X.; Sheng, S.L.; Zhang, L.M.; Chen, J.; Yang, L.L.; Zhou, H.L.; Wang, Y.X.; Li, H.B.; Zheng, Z.B. Friction and wear behaviors of a high nitrogen austenitic stainless steel Fe-19Cr-15Mn-0.66N. J. Min. Metall. Sect. B Metall. 2021, 57, 285-293. [CrossRef]

6. Zhao, H.; Ren, Y.; Dong, J.; Yang, K. The microstructure and tribological behavior of a pre-cold-deformed $0.90 \%$ nitrogen containing stainless steel. Mater. Werkst. 2018, 49, 1439-1448. [CrossRef]

7. Lin, H.; Yang, M.S.; Shu, B.P. Fretting wear behaviour of high-nitrogen stainless bearing steel under lubrication condition. J. Iron Steel Res. Int. 2020, 27, 849-866. [CrossRef]

8. Chen, Z.X.; Hu, H.X.; Guo, X.M.; Zheng, Y.G. Effect of groove depth on the slurry erosion of V-shaped grooved surfaces. Wear 2021, 488-489, 204133. [CrossRef]

9. Qiao, Y.X.; Tian, Z.H.; Cai, X.; Chen, J.; Wang, Y.X.; Song, Q.N.; Li, H.B. Cavitation erosion behaviors of a nickel-free high-nitrogen stainless steel. Tribol. Lett. 2019, 67, 1. [CrossRef]

10. Qiao, Y.X.; Chen, J.; Zhou, H.L.; Wang, Y.X.; Song, Q.N.; Li, H.B.; Zheng, Z.B. Effect of solution treatment on cavitation erosion behavior of high-nitrogen austenitic stainless steel. Wear 2019, 424-425, 70-77. [CrossRef]

11. Qiao, Y.X.; Wang, X.Y.; Yang, L.L.; Wang, X.J.; Chen, J.; Wang, Z.B.; Zhou, H.L.; Zou, J.S.; Wang, F.H. Effect of aging treatment on microstructure and corrosion behavior of a Fe-18Cr-15Mn-0.66N stainless steel. J. Mater. Sci. Technol. 2021. [CrossRef]

12. Li, J.; Yang, Y.X.; Ren, Y.B.; Dong, J.H.; Yang, K. Effect of cold deformation on corrosion fatigue behavior of nickel-free high nitrogen austenitic stainless steel for coronary stent application. J. Mater. Sci. Technol. 2018, 34, 660-665. [CrossRef]

13. Korashy, A.; Attia, H.; Thomson, V.; Oskooei, S. Fretting wear behavior of cobalt-Based superalloys at high temperature-A comparative study. Tribol. Int. 2020, 145, 106155. [CrossRef]

14. Lu, Y.; Zhu, S.Y.; Wang, X.Y.; Sui, X.D.; Zhang, S.T.; Hao, J.Y.; Zhao, T. High temperature tribological behavior of polymer-derived Ta4HfC5 nanoceramics. Tribol. Int. 2021, 156, 106859. [CrossRef]

15. Xue, Y.W.; Wu, C.H.; Shi, X.L.; Zhang, K.P.; Huang, Q.P. High temperature tribological behavior of textured CSS-42L bearing steel filled with Sn-Ag-Cu-Ti ${ }_{3} \mathrm{C}_{2}$. Tribol. Int. 2021, 164, 107205. [CrossRef]

16. Pauschitz, A.; Roy, M.; Franek, F. Mechanisms of sliding wear of metals and alloys at elevated temperatures. Tribol. Int. 2008, 41, 584-602. [CrossRef]

17. Stott, F.H. High-temperature sliding wear of metals. Tribol. Int. 2002, 35, 489-495. [CrossRef]

18. Eder, S.J.; Grutzmacher, P.G.; Ripoll, M.R.; Dini, D.; Gachot, C. Effect of temperature on the deformation behavior of copper nickel alloys under sliding. Materials 2020, 14, 60. [CrossRef]

19. Torres, H.; Varga, M.; Ripoll, M.R. High temperature hardness of steels and iron-based alloys. Mater. Sci. Eng. A-Struct. Mater. Prop. Microstruct. Process. 2016, 671, 170-181. [CrossRef]

20. Li, L.; He, K.; Sun, S.Y.; Yang, W.Z.; Yue, Z.F.; Wan, H. High-temperature friction and wear features of nickel-based single crystal superalloy. Tribol. Lett. 2020, 68, 26. [CrossRef] 
21. Pei, Y.C.; Xia, D.X.; Wang, S.R.; Cong, L.; Wang, X.L.; Wang, D.Y. Effects of temperature on the tribological properties of NM600 under sliding wear. Materials 2019, 12, 4009. [CrossRef] [PubMed]

22. Kumar, H.; Ramakrishnan, V.; Albert, S.K.; Meikandamurthy, C.; Tata, B.V.R.; Bhaduri, A.K. High temperature wear and friction behaviour of 15Cr-15Ni-2Mo titanium-modified austenitic stainless steel in liquid sodium. Wear 2010, 270, 1-4. [CrossRef]

23. Wang, L.; Tieu, A.K.; Wang, J.; Sang, P.T.; Xia, C.Y.; Zhu, H.T.; Deng, G.Y. High load capability, sticking scale inhabitation and promising lubrication of sodium carbonate coating for steel/steel contact at high temperature. Tribol. Int. 2021, 153, 106594. [CrossRef]

24. Cheng, X.W.; Jiang, Z.Y.; Kosasih, B.; Wu, H.; Luo, S.Z.; Jiang, L.Z. Influence of Cr-Rich oxide scale on sliding wear mechanism of ferritic stainless steel at high temperature. Tribol. Lett. 2016, 63, 28. [CrossRef]

25. Wang, M.J.; Wang, Y.X.; Liu, H.; Wang, J.Q.; Yan, F.Y. Interrelated effects of temperature and load on fretting behavior of SAF 2507 super duplex stainless steel. Tribol. Int. 2019, 136, 140-147. [CrossRef]

26. Torres, H.; Varga, M.; Adam, K.; Ripoll, M.R. The role of load on wear mechanisms in high temperature sliding contacts. Wear 2016, 364-365, 73-83. [CrossRef]

27. Stott, F.H.; Jordan, M.P. The effects of load and substrate hardness on the development and maintenance of wear-protective layers during sliding at elevated temperatures. Wear 2001, 250, 391-400. [CrossRef]

28. Razali, M.K.; Kim, S.W.; Irani, M.; Kim, M.C.; Joun, M.S. Practical quantification of the effects of flow stress, friction, microstructural properties, and the tribological environment on macro- and micro-structure formation during hot forging. Tribol. Int. 2021, 164, 107226. [CrossRef]

29. Lee, S.; Lee, J.; Joun, M. On critical surface strain during hot forging of lubricated aluminum alloy. Tribol. Int. 2020, 141, 105855. [CrossRef]

30. Cao, Y.J.; Sun, J.Q.; Ma, F.; Chen, Y.Y.; Cheng, X.Z.; Gao, X.; Xie, K. Effect of the microstructure and residual stress on tribological behavior of induction hardened GCr15 steel. Tribol. Int. 2017, 115, 108-115. [CrossRef]

31. Berns, H.; Koch, S. Influence of abrasive particles on wear mechanism and wear resistance in sliding abrasion tests at elevated temperatures. Wear 1999, 233-235, 424-430. [CrossRef]

32. Kumar, S.S.S.; Raghu, T.; Bhattacharjee, P.P.; Rao, G.A.; Borah, U. Work hardening characteristics and microstructural evolution during hot deformation of a nickel superalloy at moderate strain rates. J. Alloy Compd. 2017, 709, 394-409. [CrossRef]

33. Ball, A. On the Importance of work hardenning in the design of wear-resistant materials. Wear 1983, 91, 201-207. [CrossRef]

34. Llewellyn, D.T. Work hardening effects in austenitic stainless steels. Mater. Sci. Technol. 2013, 13, 389-400. [CrossRef]

35. Wang, D.P.; Zhang, H.T.; Guo, P.Y.; Sun, B.A.; Wang, Y.X. Nanoscale periodic distribution of energy dissipation at the shear band plane in a Zr-based metallic glass. Scr. Mater. 2021, 197, 4. [CrossRef]

36. Chen, Y.J.; Wang, S.H.; Hao, Y.; Pu, J.B.; Jiang, X.; Huang, L.F.; Wang, L.P. Friction and wear behavior of CrN coating on 316L stainless steel in liquid sodium at elevated temperature. Tribol. Int. 2020, 143, 106079. [CrossRef]

37. Xu, Y.W.; Jing, H.Y.; Xu, L.Y.; Han, Y.D.; Zhao, L. Effect of overload on the oxidation behavior of CF8A austenitic stainless steel in a high-temperature water environment. Corros. Sci. 2020, 162, 108219. [CrossRef]

38. Biesinger, M.C.; Payne, B.P.; Grosvenor, A.P.; Lau, L.W.M.; Gerson, A.R.; Smart, R.S.C. Resolving surface chemical states in XPS analysis of first row transition metals, oxides and hydroxides: Cr, Mn, Fe, Co and Ni. Appl. Surf. Sci. 2011, 257, 2717-2730. [CrossRef]

39. Mills, P.; Sullivan, J.L. A study of the core level electrons in iron and its three oxides by means of X-ray photoelectron spectroscopy. J. Phys. D Appl. Phys. 1983, 16, 723-732. [CrossRef]

40. Duhamel, C.; Sennour, M.; Georgi, F.; Guerre, C.; Chaumun, E.; Crépin, J.; Héripré, E.; Curières, I.D. Characterization of oxide scales formed on alloy 82 in nominal PWR Primary water at $340^{\circ} \mathrm{C}$ and in hydrogenated steam at $400{ }^{\circ} \mathrm{C}$. Corros. Sci. 2018, 131, 386-403. [CrossRef]

41. Agostinelli, E.; Battistoni, C.; Fiorani, D.; Mattogno, G.; Nogues, M. An XPS study of the electronic structure of the ZnxCd1-xCr2X4 $(X=S$, Se) spinel system. J. Phys. Chem. Solids 1989, 50, 269-272. [CrossRef]

42. Allen, G.C.; Tucker, P.M. Multiplet splitting of X-Ray photoelectron lines of chromium complexes. the effect of covalency on the 2 p core level spin-orbit separation. Inorg. Chim. Acta 1976, 16, 41-45. [CrossRef]

43. Wang, D.P.; Shen, J.W.; Chen, Z.; Chen, F.G.; Guo, P.Y.; Geng, Y.X.; Wang, Y.X. Relationship of corrosion behavior between single-phase equiatomic $\mathrm{CoCrNi}, \mathrm{CoCrNiFe}, \mathrm{CoCrNiFeMn}$ alloys and their constituents in $\mathrm{NaCl}$ solution. Acta Metall. Sin. (Engl. Lett.) 2021, 1-11. [CrossRef]

44. Quinn, T.F.J.; Sullivan, J.L.; Rowson, D.M. Origins and development of oxidational ambient temperatures wear at low ambient temperatures. Wear 1984, 94, 175-191. [CrossRef]

45. Stott, F.H. The role of oxidation in the wear of alloys. Tribol. Int. 1998, 31, 61-71. [CrossRef]

46. Jiang, J.; Stott, F.H.; Stack, M.M. The role of triboparticulates in dry sliding wear. Tribol. Int. 1998, 31, 245-256. [CrossRef]

47. Young, D.J. High Temperature Oxidation and Corrosion of Metals; Elsevier Ltd.: Amsterdam, The Netherlands, 2008.

48. Jin, X.Y.; Zhang, Y.F.; Chen, L.; Yu, J.H.; Xue, W.B. Preparation and tribological behaviors of DLC/spinel composite film on 304 stainless steel formed by cathodic plasma electrolytic oxidation. Surf. Coat. Technol. 2018, 338, 38-44. [CrossRef]

49. Lai, Z.W.; Wu, J.L.; Wen, Y.H.; Li, N.; Wang, Z.C. Study of a new type austenitic stainless steel with better wear resistance. Tribology 2009, 29, 128-133. 
50. Song, Y.L.; Yu, C.; Miao, X.; Han, X.H.; Qian, D.S.; Chen, X. Tribological performance improvement of bearing steel GCr15 by an Alternating magnetic treatment. Acta Metall. Sin. (Engl. Lett.) 2017, 30, 957-964. [CrossRef]

51. Choi, B.; Cho, I.S.; Jung, D.H.; Lee, M.G.; Jeon, Y. Friction and wear behavior of direct metal deposition on SUH3. Arch. Metall. Mater. 2019, 64, 841-844.

52. Sourani, F.; Enayati, M.H.; Taghipour, M. High-temperature oxidation and wear behavior of (Fe,Cr)Al intermetallic compound and ( $\mathrm{Fe}, \mathrm{Cr}) \mathrm{Al}_{-} \mathrm{Al}_{2} \mathrm{O}_{3}$ nanocomposites. J. Mater. Eng. Perform. 2021, 30, 3654-3669. [CrossRef]

53. Song, Q.N.; Tong, Y.; Li, H.L.; Zhang, H.N.; Xu, N.; Zhang, G.Y.; Bao, Y.F.; Liu, W.; Liu, Z.G.; Qiao, Y.X. Corrosion and cavitation erosion resistance enhancement of cast $\mathrm{Ni}$-Al bronze by laser surface melting. J. Iron Steel Res. Int. 2021. [CrossRef]

54. Blau, P.J.; Brummett, T.M. High-temperature oxide regrowth on mechanically damaged surfaces. Tribol. Lett. 2008, 32, 153-157. [CrossRef]

55. Jin, B.; Chen, G.Y.; Zhao, J.; He, Y.Y.; Huang, Y.Y.; Luo, J.B. Improvement of the lubrication properties of grease with $\mathrm{Mn}_{3} \mathrm{O}_{4}$ /graphene $\left(\mathrm{Mn}_{3} \mathrm{O}_{4} \# \mathrm{G}\right)$ nanocomposite additive. Friction 2021, 9, 1361-1377.

56. Qu, J.; Blau, P.J.; Jolly, B.C. Tribological properties of stainless steels treated by colossal carbon supersaturation. Wear 2007, 263, 719-726. [CrossRef]

57. Chandra-Ambhorn, S.; Chueaprakha, S.; Siripongsakul, T. High-temperature oxidation of the dissimilar weld between AISI 304L and Fe-15.6Cr-8.5Mn using Ar and Ar-4\%N2 shielding gas. Anti-Corros. Method. Mater. 2019, 66, 210-214. [CrossRef]

58. Li, L.L.; Wang, Z.B.; He, S.Y.; Zheng, Y.G. Correlation between depassivation and repassivation processes determined by single particle impingement: Its crucial role in the phenomenon of critical flow velocity for erosion-corrosion. J. Mater. Sci. Technol. 2021, 89, 158-166. [CrossRef]

59. Heras, E.D.L.; Santamaría, D.G.; García-Luis, A.; Cabo, A.; Brizuela, M.; Ybarra, G.; Mingolo, N.; Brühl, S.; Corengia, P. Microstructure and wear behavior of DC-pulsed plasma nitrided AISI 316L austenitic stainless steel. Plasma Processe. Polym. 2007, 4, S741-S745. [CrossRef]

60. Devaraju, A.; Perumal, A.E.; Alphonsa, J.; Kailas, S.V.; Venugopal, S. Sliding wear behavior of plasma nitrided austenitic stainless steel type AISI 316LN in the temperature range from 25 to $400{ }^{\circ} \mathrm{C}$ at $10^{-4}$ bar. Wear 2012, 288, 17-26. [CrossRef]

61. Duarte, M.C.S.; Godoy, C.; Wilson, J.A.B. Analysis of sliding wear tests of plasma processed AISI 316L steel. Surf. Coat. Technol. 2014, 260, 316-325. [CrossRef]

62. Wilson, S.; Alpas, A.T. Effect of temperature on the sliding wear performance of A1 alloys and A1 matrix composites. Wear 1996, 196, 270-278. [CrossRef]

63. Pearson, S.R.; Shipway, P.H.; Abere, J.O.; Hewitt, R.A.A. The effect of temperature on wear and friction of a high strength steel in fretting. Wear 2013, 303, 622-631. [CrossRef]

64. Mitchell, D.R.G.; Stott, F.H. The friction and wear of thin titanium nitride and silicon nitride coatings on stainless steel at temperatures to $500{ }^{\circ} \mathrm{C}$. Surf. Coat. Technol. 1992, 50, 151-160. [CrossRef] 